\title{
Disrubsi pendidikan Islam
}

\author{
Sarwadia,1, ${ }^{*}$, Umar Saiful Haq ${ }^{\mathrm{a}, 2}$, Rendiansyah a,3 \\ *a Sekolah Tinggi Ilmu Tarbiyah Madani Yogyakarta, Indonesia \\ 1 sarwadis@email.com; \\ 2 umarsh@gmail.com; \\ 3 rendiansyah@gmail.com; \\ *Correspondent Author
}

KATAKUNCI ABSTRAK

Pendidikan Islam, disrupsi, entrepreneurship, soft skill

\section{KEYWORDS}

Islamic Education, disrupsi, entrepreneurship, soft skill
Pendidikan Islam mempunyai definisi yang variatif. Goal settingnya mempersiapkan manusia supaya hidup dengan sempurna dan Bahagia serta mampu menjalankan fungsinya sebgai khalifah di bumi. Maka menjadi kebutuhan bagi Pendidikan Islam untuk bergerah dan berubah dengan mendisrusi dirinya atau justru terdisrupsi. Keadaan ini menjadi syarat eksistensi dari Pendidikan Islam dalam perhelatan kancah membangun generrasi. Olehkakarena itu mendidik mentalitas entrepreneurship dengan mengembangkan soft skill adalah tuntutan yang harus dilakukan dalam lembga Pendidikan Islam.

\section{Disrubsi pendidikan Islam}

Islamic education, from various literatures, has varied definitions. According to Athiyah Al-Abrasy, Islamic education is to prepare people to live perfectly and happily, to love their homeland, to be physically healthy, to have perfect character, to have a neatly organized mindset, to feel smooth, professional at work and sweet in speech. Meanwhile, Ahmad D. Marimba gives an understanding that Islamic education is physical and spiritual guidance based on Islamic laws leading to the formation of the main personality according to Islamic standards.

This is an open-access article under the CC-BY-SA license.



\section{Pendahuluan}

Islam sudah memiliki peran yang signifikan dalam kegaitan pendidikan, sebagaimana permulaan Islam disebarkn di tanah Makah. Rasulullah menjadikan rumah Al Arqam bin bin Al-Arqom sebagai tempat belajar dan tempat pertemuan Rasulullah dengan sahabatnya, selain itu Nabi menyampaikan pelajaran agama dirumah sendiri diMekkah. Dar Al-Arqam adalah sekolah pertama dalam Islam dan Rasulullah SAW adalah guru dan pendidik pertama (Langgulung, 2002). Dar Al- Arqam menjadi pusat kegiatan dakwah Nabi sekaligus lembaga pendidikan. Islam memberikan penekanan pada arti penting pendidikan untuk mencetak 
generasi ulul albab, yang mandiri dan independen. Pendidikan dalam Islam memuat beberapa unsur, diantaranya sebagai berikut: Pertama, Islam memiliki karakter sebagai agama misionaris. Islam berkewajiban mengajak, membimbing dan membentuk kepribadian umat sesuai dengan nilai-nilai ajaran agama. Dan pemeluknya dari masa ke masa berusaha membangun system serta lembaga dakwah sesuai dengan zamannya (Nata, 2012), sehingga melahirkan para ulama, tokoh agama, para pemimpin yang telah memberikan sumbangan untuk kemajuan bangsa.

Kedua, Islam dan Pendidikan seperti dua sisi mata uang yang tak dapat dipisahkan, keduanya berhubungan dan saling membutuhkan. Islam telah memberikan dasar perumusan visi, misi, tujuan dan berbagai aspek pendidikan yang dikenal dengan konsep Tarbiyah. Sedangkan sisi lain, Islam memerlukan pendidikan sebagai sarana yang strategis, untuk menyalurkan nilai dan praktek ajaran Islam (Nata, 2012). Pendidikan dipandang sebagai sarana yang paling strategis untuk mengangkat harkat dan martabat manusia dalam berbagai bidang kehidupan. Sehingga ajaran Islam menjadi salih likulli zaman wa makan tidak hanya menjadi cerita dan kenangan saja.

Pendidikan sebagai sarana yang strategis bertujuan untuk mengembangkan atau menmbuhkan kemampuan dasar jasmaniah (fisiologis) dan rohaniah (mental psikologis) manusia sebagai khalifah.mencapai titik seoptimal mungkin, sehingga menjadi alat yang yang berdaya guna dalam ikhtiar kemanusiaannya dalam melaksanakan tugas pokok kehidupan di dunia. Namun proses pengembangan manusia melalui pendidikan tidak otomatis akan terbentuk watak dan bakat seseorang menjadi baik, mengingat Allah telah menggariskan dalam diri manusia terdapat dua kecenderungan dua arah, yaitu kearah perbuatan fasik dan kearah ketakwaan.

Pendidikan Islam sebagai pengawal peradaban harus cerdas merespon sebuah realitas sosial yang senantiasa mengalami perubahan konsep dari masa kemasa. Islam adalah satu ajaran agama yang tetap dan tidak dapat mengalami perubahan ajaranya, namun Pendidikan Islam adalah bentuk ijtihad yang mungkin untuk berubah sesuai pada konteks masyarakat tertentu. Layaknya seperti seorang good Driver pendidikan selalu siap dan terbuka menerima tantangan dan perubahan dari zaman mesin sampai era digital, dari kecepatan kerja sampai pada kecepatan Informasi. Perubahanperubahan besar yang terjadi diberbagai bidang semakin menuntut satu perubahan yang sama dari dunia pendidikan. Rhenald Kassali mengatakan bisa sangat mungkin lembaga pendidikan mengalami pergesaran fungsi dari yang semestinya atau bahkan hilang sama sekali fungsi kalau tidak mampu merespon perubahan era ini(Kasali, n.d.).

Orang menyebut era sekarang dengan era globalisasi dan era pasar bebas. Namun ada era 
lain yang lebih "berbahaya" dari keduanya yaitu era disrupsi (disruption era). Yaitu terjadinya perubahan yang sangat radikal menembus tantangan dan hambatan. Yang paling parah dari era ini adalah terjadinya penjungkir balikan system dan tatanan yang dianggap mapan dan sudah ada sejak puluhan bahkan ratusan tahun sebelumnya, berganti dengan system baru yang dilakukan oleh anakanak muda (Lian, 2019). Sebagai contoh, di kota-kota besar bahkan ada yang sampai pelosok kota kecil, ada Gojek, Grab dan Uber. Berpuluh-puluh tahun sebelumnya sudah ada ojek. Lalu muncul anak muda yang bernama Nadiem Makarim membuat aplikasi gojek. Dia menjadi pengusaha ojek terbesar di Indonesia tanpa memiliki satupun aramada ojek (Kasali, n.d.). Taksi sudah ada dan dikenal masyarakat di dunia sejak lama. Tiba-tiba muncul grab dan uber menjadi pengusaha taksi terbesar di dunia tanpa memiliki satu armada taksipun. Konglomerat dunia punya banyak hotel. Lalu muncul anak muda yang yang mendirikan Airbnb tanpa punya satu kamar hotelpun (Kasali, n.d.). Banyak lagi contoh lainya seperti tokopedia, bukalapak, traveloka,dan banyak lagi yang intinya adalah ini yang harus disadari bahwa sedang dan sudah terjadi perubahan saat ini.

\section{Metode}

Penelitian ini digolongkan ke dalam jenis penelitian pustaka (library research), yaitu dalam proses perolehan data sesuai dengan sasaran atau masalah penelitian yang diperlukan sebuah informasi yang selengkap-lengkapnya atau sedalam-dalamnya mengenai gejala-gejala yang ada dalam lingkup obyek penelitian melalui kajian literature (Sari \& Asmendri, 2018). Dari gejala-gejala penelitian yang ada dalam penelitian ini bukanlah satu-satunya yang berdiri, melainkan saling berkaitan antara satu sama lain dalam kesatuan yang menyeluruh yang biasanya dikenal dengan pendekatan. Dalam penelitian ini, pengumpulan data menggunakan tiga metode utama yaitu: wawancara, observasi dan dokumentasi.

\section{Hasil dan Pembahasan}

\section{A. Pendidikan Islam}

Pendidikan Islam, dari berbagai literatur mempunyai definisi yang variatif. Menurut Athiyah Al-Abrasy, pendidikan Islam adalah mempersiapkan manusia supaya hidup dengan sempurna dan bahagia, mencintai tanah air, sehat jasmaninya, sempurna budi pekertinya, pola pikirnya teratur dengan rapi, perasaannya halus, profesional dalam bekerja dan manis tutur katanya (Dr. Hj. Hasnil Aida Nasution et al., 2020). Sedang Ahmad D. Marimba memberikan pengertian bahwa pendidikan Islam adalah bimbingan jasmani dan rohani berdasarkan hukum-hukum Islam menuju kepada terbentuknya kepribadian utama menurut 
ukuran-ukuran Islam (Marimba, 1964). Sedangkan menurut Syed Muhammad Naquib alAttas, pendidikan adalah suatu proses penamaan sesuatu ke dalam diri manusia mengacu kepada metode dan sistem penamaan secara bertahap, dan kepada manusia penerima proses dan kandungan pendidikan tersebut (Badaruddin \& (Bengkulu)., 2007). Dari definisi dan pengertian itu ada tiga unsur yang membentuk pendidikan yaitu adanya proses, kandungan, dan penerima. Kemudian disimpulkan lebih lanjut yaitu " sesuatu yang secara bertahap ditanamkan ke dalam diri manusia".Jadi definisi pendidikan Islam adalah pengenalan, pembimbingan perlakuan secara berangsur-angsur yang ditanamkan ke dalam diri manusia, sehingga membimbing ke arah pengenalan dan pengakuan terhadap Tuhan.

\section{B. Pesantren}

Pesantren merupakan bagian dari pendidikan nasional yang telah ada jauh sejak pra kemerdekaan dan bahkan disinyalir sebagai lembaga pendidikan yang memiliki kekhasan, keaslian, Indonesia. Pesantren juga dianggap sebagai lembaga pendidikan Islam tertua yang tidak diragukan lagi peranannya bagi perkembangan Islam nusantara (Nimim Ali, n.d.). Sebagai bagian lembaga pendidikan nasional, kemunculan pesantren dalam sejarahnya telah berusia ratusan tahun, dan disinyalir sebagai lembaga yang memiliki kekhasan, keaslian (indegeneous) Indonesia (Majid, 1997). Sebagai institusi indegeneous, pesantren muncul dan terus berkembang dari pengalaman sosiologis masyarakat di sekitar lingkungannya. Akar kultural ini barangkali sebagai potensi dasar yang telah menjadikan pesantren dapat bertahan, dan sangat diharapkan baik bagi masyarakat maupun pemerintah.

Pesantren lahir Sebagai sebuah institusi budaya yang lahir atas prakarsa dan inisiatif (tokoh) masyarakat dan bersifat otonom, sejak awal, berdirinya pesantren merupakan potensi strategis yang ada di tengah kehidupan sosial masyarakat. Kendati kebanyakan pesantren hanya memposisikan dirinya sebagai institusi pendidikan dan keagamaan, namun sejak tahun 1970-an beberapa pesantren telah berusaha melakukan reposisi dalam menyikapi berbagai persoalan sosial masyarakat, seperti ekonomi, sosial, dan politik.

Pesantren terus bermetamorfosis dan menunjukan perilaku adaptifnya, sehingga masyarakat tidak berpindah ke lain hati dan meninggalkanya. Pesantren dengan berbagai harapan dan predikat yang dilekatkan kepadanya, sesungguhnya berujung pada tiga fungsi utama yang senantiasa diembannya, yaitu: (1) sebagai pusat pengkaderan pemikir-pemikir agama (centre of exellence), (2) sebagai lembaga yang mencetak sumber daya manusia (human resource), (3) sebagai lembaga yang mempunyai kekuatan melakukan pemberdayaan pada masyarakat (agent of development) (Sarwadi Sulisno et al., 2019). Selain ketiga fungsi tersebut pesantren juga dipahami sebagai bagian yang terlibat dalam 
proses perubahan sosial (social change) di tengah perubahan yang terjadi.

Dalam keterlibatannya dengan peran, fungsi, dan perubahan yang dimaksud, pesantren memegang peranan kunci sebagai motivator, inovator, dan dinamisator masyarakat. Hubungan interaksionis-kultural antara pesantren dengan masyarakat menjadikan keberadaan dan kehadiran institusi pesantren dalam perubahan dan pemberdayaan masyarakat menjadi semakin kuat. Namun demikian harus diakui, belum semua potensi besar yang dimiliki pesantren tersebut dimanfaatkan secara maksimal, terutama yang terkait dengan kontribusi pesantren dalam pemecahan masalah-masalah sosial ekonomi umat.

Pada batas tertentu pesantren tergolong di antara lembaga pendidikan keagamaan swasta yang leading, dalam arti berhasil merintis dan menunjukkan keberdayaan baik dalam hal kemandirian penyelenggaraan maupun pendanaan (self financing). Tegasnya selain menjalankan tugas utamanya sebagai kegiatan pendidikan Islam yang bertujuan regenerasi ulama, pesantren telah menjadi pusat kegiatan pendidikan yang konsisten dan relatif berhasil menanamkan semangat kemandirian, kewiraswastaan, semangat berdikari yang tidak menggantungkan diri kepada orang lain (Sarwadi Sulisno et al., 2019).

Pengembangan ekonomi masyarakat pesantren mempunyai andil besar dalam menggalakkan wirausaha. Di lingkungan pesantren para santri dididik untuk menjadi manusia yang bersikap mandiri dan berjiwa wirausaha (Wahjoetomo, 1997). Pesantren giat berusaha dan bekerja secara independent tanpa menggantungkan nasib pada orang lain atau lembaga pemerintah swasta. Secara kelembagaan pesantren telah memberikan tauladan, contoh riil (bi al-haal) dengan mengaktualisasikan semangat kemandirian melalui usahausaha yang konkret dengan didirikannya beberapa unit usaha ekonomi mandiri pesantren. Secara umum pengembangan berbagai usaha ekonomi di pesantren dimaksudkan untuk memperkuat pendanaan pesantren, latihan bagi para santri, dan pemberdayaan mentalitas masyarakat dalam berwirausaha.

Perubahan dan pengembangan pesantren terus dilakukan, termasuk dalam menerapkan manajemen yang profesional dan aplikatif dalam pengembangannya. Karena istilah manajemen telah membaur ke seluruh sektor kehidupan manusia (Syamsudduha, 2004). Di antara pengembangan yang harus dilakukan pesantren adalah pengembangan sumber daya manusia pesantren, pengembangan komunikasi pesantren, pengembangan ekonomi pesantren, dan pengembangan teknologi informasi pesantren.

Keterampilan kerja dan berkarya diharapkan mampu dimiliki oleh para santri, sehingga nantinya terbiasa mandiri dalam mencukupi kebutuhannya. Pendidikan keterampilan (ataupun berkarya) di pesantren hendaknya tetap tidak mengesampingkan pendidikan 
agama, karena pendidikan agama merupakan inti yang harus didalami dalam setiap pesantren. Kedalaman bidang agama akan mengantarkan santri untuk menjadi panutan kepada masyarakat muslim serta menata kehidupan tradisi yang bertentangan dengan ajaran agama Islam. Bidang ekonomi nantinya santri diharapkan mengawali dan tidak pernah mengajarkan pemisahan antara ibadah ritual dan kerja. Keduanya merupakan kewajiban setiap muslim, maka kerja merupakan salah satu bentuk jihad untuk memperoleh ketenangan dalam ibadah ritual (Sarwadi Sulisno et al., 2019).

\section{Pengembangan Entrepreneurship sebagai bentuk respon Pendidikan Islam}

Entrepreneur Pendidikan adalah seseorang yang membawa inovasi, ide-ide baru yang mempunyai sumber daya berupa tenaga kerja seperti jasa dan asset yang dikombinasikan untuk menambahkan nilai yang lebih besar dalam upaya mengembangkan anak untuk mencapai kedewasaan dan menjalankan aktifitasnya agar bahagia dalam kehidupan. Dari pemaparan pada pendahuluan tentang entrepreneurship, menggambarkan bahwa entrepreneur bukanlah merupakan hal yang mudah untuk diperoleh sekejap mata tanpa melalui proses dan penanaman jiwa-jiwa mentalitas, kreatifitas dan berviskan inovatif dalam mencapai target dalam nilai-nilai kewirausahaan. Dalam hal ini, perlu bagi penulis untuk memaparkan esensial dari kreatifitas, inovasi dan karakteristik seorang entrepreneur. Dalam entrepreneur, kreativitas dan inovasi adalah hal yang penting.

Bahkan menurut Fadlullah kedua hal tersebut merupakan roh dalam dunia entrepreneur. 1Kreativitas pada dasarnya merupakan kemampuan untuk melahirkan sesuatu yang baru. Produk kreatif lahir dari proses kreatif yang identik dengan tipe berfikir divergen yang berusaha melihat berbagai dimensi yang beragam atau bahkan bertentangan menjadi suuatu produk atau pemikiran yang baru. Proses kreatif itu merentang dari : pengumpulan informasi, inkubasi, iluminasi, verifikasi/ evaluasi, dan aplikasi.

Kemampuan berfikir kreatif dapat dilihat dari kualitas respon seseorang terhadap masalah yang dihadapi. Sejauh manakah ia memiliki keunikan dan berbeda dari kebanyakan orang dalam upaya pemecahan masalah. Mengutip ungkapan dari Guilford, Fadlullah mengemukakan bahwa ada lima sifat yang mejadi ciri kemampuan berfikir kreatif (Sudarti, 2020), yaitu :

a. Kelancaran yaitu kemampuan untuk menghasilkan banyak gagasan.

b. Keluesan yaitu Kemampuan untuk mengungkapkan bermacam-macam

(alternatif) pemecahan atau pendekatan terhadap masalah

\footnotetext{
${ }^{1}$ Ibid, hlm. 77.
} 
c. Keaslian yaitu kemampuan untuk mencetuskan gagasan-gagasan dengan cara yang asli, tidak klise.

d. Elaborasi yaitu kemampuan untuk menguraikan sesuatu secara rinci.

e. Perumusan kembali Yaitu kemampuan untuk meninjau suatu persoalan berdasarkan prespektif yang berbeda dengan apa yang sudah diketahui oleh banyak orang.

Maka, pendidikan harus dapat dijadikan sebagai tempat untuk menempa mental dan jiwa entrepreneurship dan sudah saatnya untuk mengubah arah pendidikan untuk menciptakan entrepreur-entrepreneur muda dimasa mendatang.

\section{Pengembangan Soft Skill Of Entrepreneurship}

Soft Skills atau disebut juga Kematangan Berpikir sangat dibutuhkan dalam memenangkan persaingan dalam dunia usaha. Softskill adalah sesuatu yang sangat penting dalam kehidupanya agar tetap bisa survive. Kata softskill adalah bentuk idiom bahasa inggris yang terdiri dari dua kata yaitu soft dan skill.Soft diartikan atau bermakna lunak, lembut, empuk2. Sedangkan skill berarti keahlian dan ketrampilan(Sarwadi Sulisno et al., 2019). Menurut Patrick S. O’Brien dalam bukunya Making College Count, soft skill dalam entrepreneurship dapat dikategorikan ke dalam 7 area yang disebut Winning Characteristics, yaitu(Dr. Dedi Mulyadi \& Indonesia, 2021):

1. Communication skills,

2. Organizational skills,

3. Leadership,logic,

4. Effort,group skills, ethics dan

5. Hidden curriculum.

Soft skills pada dasarnya merupakan ketrampilan personal yaitu ketrampilan khusus yang bersifat non-teknis, tidak berwujud, dan kepribadian yang menentukan kekuatan seseorang sebagai pemimpin, pendengar (yang baik), negosiator, dan mediator konflik.Sedangkan Hard skill bersifat teknis dan biasanya sekedar tertulis pada bio data atau CV seseorang yang mencakup pendidikan, pengalaman, dan tingkat keahlian (teknis).

Soft Skills bisa juga dikatakan sebagai ketrampilan intrapersonal dan interpersonal seperti kemampuan berkomunikasi dan bekerja sama dalam sebuah kelompok. Intrapersonal softskill (Suranto \& Rusdianti, 2018), Kecerdasan ini sangat samar, jika tidak jeli melihatnya

\footnotetext{
${ }^{2}$ Kamus Indonesia-Inggri, Inggris-Indonesia, Robert K. Cuninggham.hlm 260.
} 
sebagai sebuah potensi ia tidak hanya akan lewat begitu saja, tapi juga bahkan hanya terlihat sebagai sebuah kelemahan. Kecerdasan intrapersonal adalah kecerdasan berkaitan dengan kemampuan untuk mengakses kehidupan perasaan sendiri dan memilah emosi-emosi pribadi, kesabaran terhadap kekuatan dan kelemahan diri.Kecerdasan ini ditandai dengan adanya komunikasi dalam pribadi (Meks Lagibu, Abd. Kadim Masaong, 2018). Pada saat kanak-kanak nampak pada anak yang sering berbicara sendiri. Setelah dewasa maka individu tetap berkomunikasi dengan dirinya sendiri baik sebelum atau setelah berkomunikasi dengan orang lain tetapi tidak disuarakan. Khusus orang auditory learner masih nampak ucapan ketika ia berbicara dengan dirinya sendiri.

\section{Intrapersonal soft skill of entrepreneurship}

Kecerdasan ini juga merupakan kecerdasan berkaitan dengan keyakinan diri.Oleh karena itu kecerdasan ini perlu dikembangkan melalui pernyataan positif baik positif feeling ataupun positif thinking.Banyaknya pengalaman yang kuran baik dan kurangnya tantangan dalam hidup maka kecerdasan intrapersonal individu kurang berkembang optimal. Yang termasuk Intrapersonal Softskill Adalah :

a. Mengenali Emosi Diri Sendiri dan Efeknya

Setiap Individu pasti memiliki emosi yang berbeda. Emosi tersebut pasti dipengaruhi oleh lingkungan ataupun berasal dari psikis seseorang yang sedang tidak stabil. Emosi setiap individu yang berbeda akan menyebabkan pola hubungan yang berbeda pula karena emosi bisa menimbulkan hubungan sosial yang negatif jika pengelolaannya tidak tepat. Oleh karena itu, setiap individu sebaiknya bertanya pada diri sendiri, "saya tergolong tipe kepribadian seperti apa? Dan bagaimana saya mengendalikan emosi saya ketika melakukan interaksi dengan orang lain?"

Para ahli psikologi menyatakan bahwa emosi merupakan hasil dari cara orang memandang situasi. Emosi adalah hasil cara (proses) berfikir. Proses berfikir tersebut terjadi sebelum seseorang merasakan suatu emosi. Dengan demikian menunjukkan bahwa emosi yang dialami oleh seseorang dapat dikendalikan. Pengendalian emosi dapat dilakukan dengan melalui tahap-tahap sebagai berikut (Scheinfeld, 2003) :

1) Tahap kesadaran emosi (emosional awareness). Tahap menyadari emosi yang dialami, ciri-ciri orang yang menyadari emosi yang dialami, dapat mendeskripsikan emosi, mengetahui penyebab munculnya emosi, mengetahui reaksi tubuh, mengetahui pengaruh emosi bagi dirinya.

2) Tahap Pengelolaan emosi yaitu tahap untuk mengetahui apa dibalik emosi dan cara mengatasinya. Ciri-ciri orang yang dapat mengelola emosi dapat bersikap 
tenang dan berfikir sebelum bertindak, dapat melihat situasi dengan pandangan yang lebih positif, mempunyai banyak cara untuk meredakan emosi. Adapun contoh pengendalian emosi, seperti setiap tindakan harus didasarkan pada akal sehat, berfikir tentang akibat negatif yang mungkin terjadi, berusaha untuk memaafkan kesalahan orang lain. Pengendalian emosi, bukan berarti hanya meredam rasa tertekan atau menahan gejolak emosi, akan tetapi juga bisa berarti dengan sengaja menghayati suatu emosi, termasuk yang tidak menyenangkan. Pengendalian emosi tidak sama dengan pengendalian berlebihan, yaitu penyangkalan semua perasaan dan spontanitas. Bahkan kendali diri yang berlebihan dapat mendatangkan kerugian bagi fisik maupun mental. Orang yang mematikan perasaan negatif yang kuat yang menyebabkan meningkatkan denyut jantung, sekaligus naiknya tekanan darah. Apabila penekanan emosi seperti ini menjadi kronis, kemampuan berfikir menjadi rusak, terganggunya hubungan sosial. Pegendalian diri terhadap emosi merupakan salah satu keterampilan hidup (life skill) yang dapat dilatihkan kepada setiap orang.

Dari sini dapat dipahami bahwasanya emosi tidak sekedar luapan marah tetapi marah memang merupakan salah satu dari definisi dari emosi sendiri karena emosi bisa meliputi perasaan senang, sedih, suka, benci, dan sebagainya. Kemudian tingkat emosi masing-masing orang berbeda. Kepada siapapun sebaiknya dapat mengendalikan emosi dan tunjukkan emosi sebatas wajar dan janganlah berlebihan karena kita hidup dalam lingkungan yang melibatkan banyak pihak sehingga harus memperhatikan kita berada dimana dan dengan siapa kita berinteraksi.

\section{b. Mengetahui Kekuatan dan Batas-Batas Diri Sendiri}

Mengenal kekuatan dan kelemahan diri sendiri itu penting bagi para calon entrepreneur. Dengan kita mengetahui dimana kekuatan kita, kita belajar untuk memacunya, mengembangkannya dan berusaha semaksimal mungkin untuk mencapai yang terbaik lewat kekuatan itu. Kita juga perlu mengenal kelemahan kita, supaya kita belajar melihat dan mempelajari dengan baik, batas-batas kekuatan kita, menjadikannya peringatan bagi kita agar tidak sombong dan bergantung pada kekuatan diri sendiri.

Manfaat yang bisa kita rasakan adalah upaya pengembangan diri dapat lebih efektif. Jika kita menginternalisasi dan menghayati akan kekuatan dan batas kemampuan diri, maka kita akan sampai kepada kesimpulan bahwa peluang ada dibalik dua hal tersebut. Mengetahui kekuatan dan batas diri juga dapat membantu 
kita mengetahui kemampuan dan bakat dalam diri kita. Demikian juga sebaliknya jika kita mengenal diri kita maka kita juga mengetahui kekurangan dan kelemahan yang ada pada diri kita. Dengan demikian kita dapat menjadi diri kita sendiri.

Kunci proses mengetahui kekuatan diri adalah mengenal diri sendiri. Ini tidak hanya berlaku bagi keberhasilan di bidang karier, melainkan juga di berbagai bidang kehidupan lainnya, termasuk keluarga, sosial masyarakat, spiritual dan tentunya ide kreatif berwirausaha. Dengan mengenal diri sendiri, seseorang mengetahui apa yang mesti jadi tujuan hidupnya. Ia menyadari kemampuan dan bakat-bakatnya serta tahu bagaimana menggunakannya demi mencapai tujuan tersebut.

c. Pembentukan Kemampuan Mengatur Diri (Self Management)

Manajemen diri (self management) adalah kemampuan untuk mengelola pikiran, perilaku dan perasaan dalam diri seseorang untuk mencapai suatu tujuan tertentu. Dalam manajemen diri terkandung tiga usur utama yakni perasaan (affection), perilaku (behavior) dan pikiran (cognition). Konsep manajemen diri ini mulai dikenalkan oleh Brian Yates (1989) dan pada tahun 1999 self management ini disempurnakan oleh O'Keefe dan Berger dalam bukunya yang berjudul "self management on college student: approach ABC" (Scheinfeld, 2003). Manajemen diri ini sangat berguna bagi siapa saja yang ingin mengelola dirinya dalam kehidupan yang lebih baik. Kemampuan ini mencakup:

1) Kemampuan Mengelola Emosi dan Desakan-Desakan Keadaan

Mengelola emosi diri adalah kemampuan menangani perasaan agar dapat terungkap dengan tepat, termasuk menangani perasaan yang tidak menyenangkan secara akurat, berikut memahami alasan dibaliknya. Orang yang mampu mengelola emosinya dengan baik, ia akan lebih berfikir positif terhadap diri sendiri, usahanya, keluarga dan masyarakat serta lebih mampu mengelola marah, sehingga mampu mengungkapkannya dengan tepat dan lebih mampu menangani ketegangan jiwa.

2) Keluwesan Dalam Menghadapi Perubahan

Sikap terbuka (open mindedness) amat besar pengaruhnya dalam menumbuhkan komunikasi yang efektif. Ada beberapa alasan yang menjadikan sikap terbuka menghadapi perubahan berdampak besar dalam dunia entrepreneurnya, yaitu: Pertama, seorang yang bersifat terbuka biasanya menilai pesan secara obyektif, dengan menggunakn data dan keajegan logika. Kedua, orang terbuka rata-rata lebih mampu membedakan sesuatu dengan mudah, mampu melihat nuansa-nuansa. Ketiga, orang yang bersifat terbuka lebih banyak 
berorientasi pada isi (content) ketimbang orangnya, bungkus atau polesanpolesannya. Keempat, orang ini mau mencari informasi dari berbagai sumber, tidak hanya puas dengan satu nara sumber. Kelima, ia lebih profesional dan bersedia tanpa malu-malu dan tanpa khawatir bersedia untuk mengubah kepercayaannya, keyakinannya, pendapatnya, jika memang itu terbukti salah.

\section{d. Pembentukan Self Motivation Ability}

Kesuksesan adalah impian setiap orang. Banyak orang mengejar impian ini dengan berbagai cara. Bahkan ada yang menghalalkan segala cara untuk dapat meraih apa yang ia anggap sebagai kesuksesan. Sukses memang memiliki banyak makna. Ada yang menganggap sukses itu identik dengan kekayaan, kedudukan yang tinggi dan popularitas. Tapi anggapan itu sebetulnya semu. Sukses yang sesungguhnya tidak terkait dengan materi dan status yang ada di luar kita. Sukses sesungguhnya ada di dalam hati. Sukses adalah perasaan bahagia yang muncul dari dalam hati. Perasaan bahagia karena telah meraih apa yang diyakini sebagai kebenaran dan menjalaninya dengan konsisiten. Dengan konsistensi menjalani kebenaran ini, seseorang akan berusaha mencapai apa yang dicita-citakannya. Inilah makna sukses sesungguhnya yang sering dilupakan orang.

Namun apapun makna sukses yang dipahami orang,sukses tak datang begitu saja. la membutuhkan syarat, dan syarat itu mesti dilakukan dengan konsisten. Syarat sukses ada tiga, yakni semangat, visi, dan aksi. Orang yang sukses membutuhkan semangat (motivasi), karena tanpa semangat, sukses akan diraih dalam waktu yang lambat. Bahkan mungkin tak tercapai. Kalaupun sukses dapat diraih, namun jika tanpa semangat, hasilnya tak akan optimal. "Kalah" dibandingkan kesuksesan yang dapat diraih orang lain. Padahal tadinya mereka berangkat dari "titik" yang sama.

Orang yang ingin sukses juga membutuhkan visi. Tanpa visi (tujuan) tak ada yang namanya sukses, Yang ada hanyalah surprise (kejutan), yang mungkin tak sesuai dengan harapan. Semangat tanpa visi ibarat orang yang berlari di tempat Hanya kesibukan yang didapat, tapi bukan kesuksesan. Begitu pula dengan aksi (pelaksanaan). Orang yang ingin sukses harus beraksi. Harus mengerjakan apa yang menjadi visinya. Tanpa aksi, walau ada semangat dan visi, sukses hanyalah impian belaka. Tanpa aksi, sukses hanya sekedar rencana di atas kertas. Tak mungkin ada kesuksesan, jika tidak dilaksanakan apa yang menjadi visinya.

Sebagai salah satu syarat sukses, semangat (motivasi) mutlak diperlukan bagi setiap orang. Motivasi menjadi modal dan pemicu awal sebelum orang berpikir 
tentang visi dan beraksi. Tanpa motivasi, tak mungkin seseorang memiliki visi yang jelas dan jauh ke depan. Tanpa motivasi, visi seseorang akan dangkal, sehingga sebetulnya tak dapat disebut sebagai "visi". Lebih tepat mungkin disebut "nafsu". Yakni keinginan sesaat untuk meraih kesenangan apa yang ada di depan mata. Tak ada keinginan untuk meraih cita-cita tinggi dengan melalui pengorbanan dan perjuangan. Tanpa motivasi, aksi juga hanya sekedar retorika. Tak akan terwujud walau sering diucapkan dan dipikirkan. Perbedaan antara orang sukses dan gagal letaknya disini. Orang sukses berbuat untuk berpikir. Orang gagal berpikir untuk berbuat. Orang gagal sekedar berpikir, tapi takut berbuat, sehingga tak pernah berbuat.

Untuk selalu memiliki motivasi yang tinggi, kita harus mampu memotivasi diri kita sendiri, jika kita tergantung pada orang lain atau lingkungan untuk memotivasi kita, maka motivasi yang muncul tidak akan sampai pada tingkat "menggebu-gebu". Kalaupun sampai pada tingkat "menggebu-gebu" sifatnya amat situasional dan temporer, tergantung pada stimulus lingkungan. Tidak bisa menjadi semangat yang langgeng dan lama. Sebab seperti yang dikatakan Herzberg dalam teori HigieneMotivator.Ada dua jenis motivasi, yakni motivasi intrinsik (motivator) dan motivasi ekstrinsik (higiene) (Daniels, 2004). Motivasi intrinsik adalah motivasi yang berasal dari dalam diri sendiri. Sedang motivasi ekstrinsik adalah motivasi yang berasal dari lingkungan. Kontinum motivasi intrinsik adalah dari kepuasan rendah kepada kepuasaan tinggi.

Sedang kontinum motivasi ekstrinsik dari ketidakpuasan rendah kepada ketidakpuasan tinggi. Artinya, motivasi ekstrinsik tidak mampu membuat orang puas. la hanya mampu mengeliminir ketidakpuasan, jadi, kepuasan hanya dapat diraih dengan motivasi intrinsik (motivasi dari dalam diri sendiri).

Dengan kata lain, kepuasan hanya dapat diraih jika kita mampu memotivasi diri sendiri. Sebab dengan memotivasi diri sendiri, kita berarti memotivasi diri untuk melakukan sesuatu bagi kepuasan kita sendiri. Keinginan meraih kepuasan itu yang membuat kita lebih termotivasi untuk berbuat sesuatu. Hal ini akan membuat kita memiliki semangat yang lebih besar daripada ketika kita disemangati orang lain.

\section{Interpersonal soft skill of entrepreneurship}

Kecerdasan interpersonal menunjukkan kemampuan seseorang untuk peka terhadap perasaan orang lain. Mereka cenderung untuk memahami dan berinteraksi dengan orang lain sehingga mudah bersosialisasi dengan lingkungan sekelilingnya. Kecerdasan 
semacam ini dikenal juga sebagai kecerdasan sosial, yang selain kemampuan menjalin persahabatan yang akrab dengan teman, juga mencakup kemampuan seperti memimpin, mengorganisasi, menangani perselisihan antarteman, memperoleh simpati dari rekannya.

Dengan demikian kecerdasan interpersonal adalah kapasitas yang dimiliki oleh seseorang untuk dapat memahami dan dapat melakukan interaksi secara efektif dengan orang lain. Kecerdasan interpersonal akan dapat dilihat dari beberapa oranng seperti; guru yang sukses, pekerja sosial, aktor, politisi. Saat ini orang mulai menyadari bahwa kecerdasan interpersonal merupakan salah satu faktor yang sangat menentukan kesuksesan seseorang.Untuk mempermudah, kemampuan tersebut terbagi dalam empat pokok interpersonal soft skill ability, yaitu:

\section{a. Listening ability}

Kemampuan mendengarkan orang lain adalah hal pertama yang harus dimiliki oleh seorang entrepreneur. Hampir setiap orang mampu berbicara panjang lebar bahkan sampai berjam-jam tanpa merasa bosan dan letih. Namun, sangat jarang ada orang yang mampu mendengarkan orang lain secara serius selama berjam-jam pula, terlebih jika yang harus di dengar adalah masalah pribadi lawan bicaranya. Oleh karena itu listening ability menjadi skill pertama dalam interpersonal skill. Mendengarkan adalah kunci untuk semua komunikasi yang efektif, tanpa kemampuan untuk mendengarkan secara efektif pesan yang mudah disalahpahami, Komunikasi rusak dan pengirim pesan dapat dengan mudah menjadi frustasi.

Keterampilan mendengarkan yang baik juga memiliki manfaat dalam kehidupan pribadi kita, termasuk: lebih banyak teman dan jaringan sosial, peningkatan harga diri dan kepercayaan diri, nilai yang lebih tinggi dalam pekerjaan akademis dan kesehatan meningkat dan kesejahteraan. Penelitian telah menunjukkan bahwa, sementara berbicara meningkatkan tekanan darah, mendengarkan membawa ke bawah.

Mendengarkan berarti memperhatikan tidak hanya cerita, tapi bagaimana itu mengatakan, penggunaan bahasa dan suara, dan bagaimana orang lain menggunakan tubuhnya. Dengan kata lain, itu berarti menyadari pesan baik verbal dan non-verbal. Kemampuan Anda untuk mendengarkan secara efektif tergantung pada sejauh mana Anda menilai dan memahami pesan-pesan."Cara yang paling mendasar dan kuat untuk terhubung ke orang lain adalah dengan mendengarkan, hanya mendengarkan (Folkman \& Zenger, 2010). Mungkin hal yang paling penting kita pernah saling memberi perhatian kita adalah "Rachel Naomi Remen. 
b. Providing Feedback Ability

Feedback atau umpan balik adalah sebuah proses penyampaian informasi tentang apa yang kita rasakan terhadap apa yang dilakukan dan dikatakan orang lain. Syarat utama dalam providing feedback adalah mengetahui apakah feedback tersebut betul-betul bermanfaat bagi si penerima. Dalam dunia kerja, para supervisor atau manager senantiasa memberikan feedback kepada anggotanya, oleh karena itu mereka membutuhkan keterampilan khusus untuk kegiatan tersebut agar anggota mereka dapat merasakan memanfaatkannya. providing feedback meliputi(Folkman \& Zenger, 2010):

1) Fokus pada perilaku yang spesifik

2) Feedback harus memiliki hubungan

3) Berikan feedback pada waktunya

4) Pastikan umpan balik kita dapat dimengerti

5) Jika umpan baliknya bersifat negatif, pastikan perilakunya berada di dalam kemampuan si penerima.

c. Persuading ability

Kecerdasan persuasi yang dapat disebut juga sebagai kecerdasan membujuk, masih terbilang baru dalam dunia bisnis maupun kehidupan sehari-hari daripada dua kecerdasan lain yang pernah kita kenal yakni IQ (Intelligence Quotient) dan EQ (Emotional Quotient).

Uniknya, kecerdasan persuasi yang merupakan faktor pendukung kesuksesan bisnis ini tidak dapat dipelajari di sekolah. Namun tanpa disadari kecerdasan persuasi memiliki arti, seperti yang dikatakan oleh Napoleon Hill dalam bukunya yang laris terjual yaitu Think And Grow Rich dan Grow Rich Through Persuasion, kemampuan persuasi adalah keterampilan yang paling penting bagi seseorang untuk mencapai potensinya yang paling hebat (Hill, 2021). Menguasai seluruh keterampilan dalam buku ini, berarti memosisikan diri pada sebuah tingkatan dimana pendengar menjadi bagian yang alami dari diri kita. Orang-orang akan merasa nyaman berada di dekat kita, mempu mengerti kebutuhan dan kerisauan pendengar dengan cara yang wajar dan tidak mengancam.

\section{d. Resolving Conflict Ability}

Menyelesaikan konflik tidak saja memerlukan keahlian memetakan anatomi konflik tetapi juga kemampuan menelusuri pada tingkat mana konflik tersebut terjadi. Apakah pada tingkat sistemik, pada tingkat manajerial, atau pada tingkat pragmatik. Untuk menyelesaikan konflik pada tingkatan masing-masing tadi selain 
memerlukan pendekatan tersendiri juga memerlukan keterampilan manajerial yang efektif.

\section{Simpulan}

Pendidikan Islam dalam hal ini Pesantren sudah memiliki kontribusi yang sangat banyak terhadap peningkatan kemajuan Sumber Daya Manusia masyarakat muslim dari masa sebelum Indosesia lahir sampai saat ini. Namun diera disrupsi ini, Pendidikan Islam juga perlu untuk merespon kebutuhan pendidikan sebagai solusi. Salah satu solusinya adalah perlunya menumbuhkan kemampuan softskill entrepreneurship baik intrapersonal maupun interpersonal sebagai suatu kemampuan untuk survive, kepekaan membaca setiap potensi dilingkungan sekitarnya kemudian mengoptimalkanya.

\section{Daftar Pustaka}

Badaruddin, K., \& (Bengkulu)., S. T. A. I. N. (STAIN). (2007). Filsafat pendidikan Islam: Analisis pemikiran Prof $\mathrm{Dr}$ Syed Muhammad Al-Naquib al-Attas. Pustaka Pelajar. https://books.google.co.id/books?id=ucChNQAACAAJ

Daniels, C. (2004). Black Power Inc.: The New Voice of Success. Wiley. https://books.google.co.id/books?id=4030wHEEMB0C

Dr. Dedi Mulyadi, S. E. M. M., \& Indonesia, M. S. (2021). FAKTOR-FAKTOR MANAJERIAL DALAM PENGELOLAAN USAHA PENGGILINGAN PADI. Media Sains Indonesia. https://books.google.co.id/books?id=qPshEAAAQBAJ

Dr. Hj. Hasnil Aida Nasution, M. A., Pustaka, S. M., \& 241/JTI/2019, A. I. (2020). PATOLOGI SOSIAL DAN PENDIDIKAN ISLAM KELUARGA. SCOPINDO MEDIA PUSTAKA. https://books.google.co.id/books?id=d23IDwAAQBAJ

Folkman, J. R., \& Zenger, J. H. (2010). The Power of Feedback: 35 Principles for Turning Feedback from Others into Personal and Professional Change. Wiley. https://books.google.co.id/books?id=Ig6U038k8Q8C

Hill, N. (2021). Napoleon Hill. Collected works (Illustrated): Think and Grow Rich, The Law of Success. Strelbytskyy Multimedia Publishing. https://books.google.co.id/books?id=qF0uEAAAQBA]

Kasali, R. (n.d.). Disruption: tak ada yang tak bisa diubah sebelum dihadapi motivasi saja tidak cukup. PT Gramedia Pustaka Utama. https://books.google.co.id/books?id=R5dUswEACAAJ

Langgulung, H. (2002). Peralihan paradigma dalam pendidikan Islam dan sains sosial. Gaya Media Pratama. https://books.google.co.id/books?id=-BL0AAAACAAJ

Lian, B. (2019). Revolusi Industri 4.0 Dan Disrupsi, Tantangan Dan Ancaman Bagi Perguruan Tinggi. Prosiding Seminar Nasional Pendidikan Program Pascasarjana Universitas Pgri Palembang 12 Januari 2019, 2, 364-370.

Majid, N. (1997). Bilik-bilik pesantren: sebuah potret perjalanan. Paramadina. https://books.google.co.id/books?id=ln2dAAAAMAAJ

Marimba, A. D. (1964). Pengantar filsafat pendidikan Islam. Penerbit Almáarif. https://books.google.co.id/books?id=XcruEBKNDJIC

Meks Lagibu, Abd. Kadim Masaong, I. H. (2018). Pengaruh kecerdasan interpersonal, kecerdasan intrapersonal, dan kecerdasan sosial terhadap kreativitas guru Sekolah Menengah Pertama Negeri di Kecamatan Paguyaman Kabupaten Boalemo. JPs: Jurnal Riset Dan Pengembangan Ilmu Pengetahuan, 03(1), 95-102. http://ejurnal.pps.ung.ac.id 
Nata, A. (2012). Kapita selekta pendidikan Islam: isu-isu kontemporer tentang pendidikan Islam. Rajagrafindo Persada. https://books.google.co.id/books?id=Bti8MgEACAAJ

Nimim Ali, S. I. M. P. (n.d.). PENDIDIKAN PESANTREN BERBASIS WIRAUSAHA. Global Aksara Pers. https://books.google.co.id/books?id=HNOzEAAAQBAJ

Sari, M., \& Asmendri. (2018). Penelitian Kepustakaan (Library Research) dalam Penelitian Pendidikan IPA. Penelitian Kepustakaan (Library Research) Dalam Penelitian Pendidikan IPA, 2(1), 15. https://ejournal.uinib.ac.id/jurnal/index.php/naturalscience/article/view/1555/1159

Sarwadi Sulisno, M. P. I., Dhian Marita Sari, M. P. I., \& Amin Nasrullah, L. M. E. K. (2019). Manajemen Pengembangan Softskill Entrepreneurship Santri. CV. Pilar Nusantara. https://books.google.co.id/books?id=ZHcqEAAAQBAJ

Scheinfeld, R. (2003). The 11th Element: The Key to Unlocking Your Master Blueprint For Wealth and Success. Wiley. https://books.google.co.id/books?id=dajjuVdbF4YC

Sudarti, D. O. (2020). Mengembangkan Kreativitas Aptitude Anak dengan Strategi Habituasi dalam Keluarga. JURNAL Al-AZHAR INDONESIA SERI HUMANIORA, 5(3), 117. https://doi.org/10.36722/sh.v5i3.371

Suranto, \& Rusdianti, F. (2018). Pengalaman Berorganisasi dalam Membentuk Soft Skill Mahasiswa. $\begin{array}{llll}\text { Jurnal Pendidikan Dan Ilmu Sosial, } & \text { 28(1), }\end{array}$ http://journals.ums.ac.id/index.php/jpis/article/view/6772/4099

Syamsudduha, S. (2004). Manajemen pesantren: teori dan praktek. Grha Guru. https://books.google.co.id/books?id=QW6dAAAAMAAJ

Wahjoetomo. (1997). Perguruan tinggi pesantren: pendidikan alternatif masa depan. Gema Insani Press. https://books.google.co.id/books?id=m4KjAAAACAAJ 